\title{
ANALISIS PENGETAHUAN MAHASISWA TENTANG KARIES GIGI TERHADAP INDEKS DMF-T PADA MAHASISWA STIKES YARSI JURUSAN KEPERAWATAN BUKITTINGGI
}

\author{
Muhammada Faisal, Ovie Yolanda \\ Poltekkes Kemenkes Padang
}

\begin{abstract}
Oral and dental health has experienced an increase in the last century but the high rate of caries is a very serious problem. This study aims to look at the description of student knowledge about dental caries on the DMF-T index in Yarsi STIKES students in the Nursing Department. This study used a descriptive type of research. The study population was all STIKES Yarsi students in the Nursing Department with a sample of 47 people taken by judgment sampling technique. The results of the study showed that 37 people (78\%) had sufficient knowledge and 10 people (22\%) had good knowledge about dental caries, while 24 people (51\%) have DMF-T index with bad criteria and 23 people (49\%) have DMF-T index with good criteria. The conclusion in this study is the knowledge of students about dental caries with sufficient criteria to have an ugly DMF-T index. It is recommended to respondents to increase knowledge about how to maintain dental and oral health.
\end{abstract}

Keywords: Knowledge, Dental Caries, DMF-T Index

\section{ABSTRAK}

Kesehatan gigi dan mulut telah mengalami peningkatan pada abad terakir tetapi tingginya angka karies menjadi masalah yang sangat serius. Penelitian ini bertujuan untuk melihat gambaran pengetahuan mahasiswa tentang karies gigi terhadap indeks DMF-T pada mahasiswa STIKES Yarsi Jurusan Keperawatan.m Penelitian ini menggunakan jenis penelitian deskriptif. Populasi penelitian adalah seluruh mahasiswa STIKES Yarsi Jurusan Keperawatan dengan sampel sebanyak 47 orang diambil dengan teknik judgement sampling.mHasil penilitian menunjukkan bahwa 37 orang (78 \%) memiliki pengetahuan cukup dan 10 orang (22\%) memiliki pengetahuan baik tentang karies gigi, sedangkan 24 orang (51\%) memiliki indeks DMF-T dengan kriteria jelek dan 23 orang (49\%) memiliki indeks DMF-T dengan kriteria baik. Kesimpulan dalam penelitian ini yaitu pengetahuan mahasiswa tentang karies gigi dengann kriteria cukup mempunyai indeks DMF-T jelek. Disarankan kepada responden untuk lebih meningkatkan pengetahuan tentang cara menjaga kesehatan gigi dan mulut.

Kata Kunci : Pengetahuan, Karies Gigi, Indeks DMF-T

\section{PENDAHULUAN}

Kesehatan gigi merupakan suatu masalah kesehatan yang membutuhkan penanganan yang komprehensif, karena masalah gigi memiliki dimensi yang luas serta mempunyai dampak seperti faktor fisik, mental, serta sosial bagi individu yang menderita penyakit gigi. Hasil Riset Kesehatan Dasar (Riskesdas) tahun 2013 yaitu 22,2 \% penduduk provinsi Sumatera Barat memiliki masalah gigi dan mulut dan indeks DMF-T untuk provinsi 
sumatera barat adalah 4,7 (Riskesdas, 2013)

Seseorang baru menyadari pentingnya gigi tersebut bila giginya sudah berlubang dan menimbulkan rasa sakit dan berdenyut terus-menerus. Gigi yang sakit dapat menyebabkan para penderita tidak dapat bekerja atau berpikir dengan baik. Dengan cara pengobatan saja, karies gigi di dalam masyarakat tidak dapat diatasi, terlebih lagi di Indonesia dimana perbandingan dokter gigi dan penduduk $1: 35.000$, jadi kita juga harus memperhatikan bidang pencegahan sebagaimana berlaku untuk semua penyakit (Tarigan, 2013)

Karies merupakan suatu penyakit jaringan keras gigi, yaitu email, dentin, dan sementum, yang disebabkan oleh aktifitas suatu jasad renik dalam suatu karbohidrat yang dapat diragikan. Tandanya adalah adanya demineralisasi jaringan keras gigi yang kemudian diikuti oleh kerusakan bahan organiknya. Akibatnya terjadi invasi bakteri dan kematian pulpa serta penyebaranya infeksinya ke jaringan periapikal yang dapat menyebabkan nyeri. Walaupun demikian mengingat demineralisasi terjadi, pada stadium yang sangat dini penyakit ini dapat dihentikan (Kidd, 2013)

Pengetahuan merupakan dasar terbentuknya suatu perilaku. Seseorang dikatakan kurang pengetahuan apabila dalam suatu kondisi dia tidak mampu mengenal, menjelaskan, dan menganalisis suatu keadaan. ${ }^{6}$ Ketika seseorang berada dalam tingkatan pengetahuan yang lebih tinggi, maka perhatian terhadap kesehatan gigi akan semakin tinggi. Pengetahuan atau kognitif merupakan domain yang sangat penting dalam membentuk tindakan seseorang. ${ }^{7}$ Rendahnya pengetahuan mengenai kesehatan merupakan faktor dari predisposisi dari perilaku kesehatan yang mengarah kepada timbulnya penyakit. Pengetahuan ini erat pula kaitannya dengan sikap seseorang tentang penyakit dan upaya pencegahannya (Harto,2010)

Indeks yang digunakan untuk mengukur indeks karies gigi adalah indeks DMF-T. Jumlah indeks DMF-T seseorang individu diperoleh dengan menjumlahkan masing-masing komponen D, M, dan F untuk mengukur DMF-T suatu kelompok maka DMF-T individu dijumlahkan lalu dibagi dengan jumlah individu dalam kelompok tersebut (Rita, 2006)

Studi pendahuluan yang dilakukan dengan wawancara kepada 10 orang mahasiswa STIKES Yarsi Jurusan Keperawatan tentang pengetahuan mereka seputar karies, diketahui sebagian dari mahasiswa jurusan keperawatan tersebut sudah mengetahui apa itu karies. Dan setelah dilakukan pemeriksaan didapatkan semuanya memiliki karies gigi.

Penelitian ini bertujuan ingin mengetahui gambaran pengetahuan mahasiswa tentan karies gigi terhadap indeks DMF-T pada mahasiswa STIKES Yarsi Jurusan Keperawatan. 


\section{METODE PENELITIAN}

Desain penelitian yang digunakan adalah metode penelitian deskriptif. Penelitian di STIKES Yarsi Jurusan Keperawatan Bukittinggi pada September 2016. Populasi penelitian ini adalah seluruh mahasiswa STIKES Yarsi Jurusan Keperawatan Bukittinggi dengan sampel penelitian mahasiswa tingkat 1 yang berjumlah 47 orang mahasiswa dengan teknik pengambilan sampel teknik "judgement sa dengan cara memakai proses seleksi bersyarat dengan syarat ; 1) Mahasiswa Jurusan Keperawatan STIKES Yarsi; 2) Bersedia untuk menjadi responden. Pengambilan data dengan pemeriksaan gigi langsung dan memberikan pertanyaan kepada subyek penelitian dengan menggunakan kuesioner. Data dikelompokkan dan dianalisis setelah itu dimasukkan kedalam kategori sampel berbentuk tabel distribusi frekuensi.

\section{HASIL PENELITIAN}

Berdasarkan hasil penelitian yang telah dilakukan terhadap 47 orang responden penelitian tentang gambaran pengetahuan mahasiswa tentang karies gigi terhadap indeks DMF-T pada mahasiswa STIKES Yarsi Jurusan Keperawatan Bukittinggi diperoleh gambaran responden secara umum yaitu berdasarkan umur dan jenis kelamin pada mahasiswa STIKES Yarsi Jurusan Keperawatan Bukittinggi pada tabel berikut ini :

Tabel 1. Distribusi Frekuensi Responden Berdasarkan Jenis Kelamin di STIKES Yarsi Jurusan Keperawatan Bukittinggi

\begin{tabular}{cccc}
\hline No & Jenis kelamin & Frekuensi & Persentase (\%) \\
\hline 1 & Laki-laki & 9 & 19 \\
\hline 2 & Perempuan & 38 & 81 \\
\hline & Jumlah & 47 & 100 \\
\hline
\end{tabular}

berdasarkan tabel diatas diketahui bahwa responden yang berjenis kelamin perempuan lebih banyak dibandingkan responden yang berjenis kelamin laki-laki yaitu sebanyak 38 orang $(80,86 \%)$ yang merupakan responden terbanyak dari keseluruhan responden.

Tabel 2. Distribusi Frekuensi responden berdasarkan umur di STIKES Yarsi Jurusan Keperawatan Bukittinggi

\begin{tabular}{cccc}
\hline No & Umur & Frekuensi & Persentase (\%) \\
\hline 1 & 18 & 4 & 9 \\
\hline 2 & 19 & 23 & 49 \\
\hline 3 & 20 & 16 & 34 \\
\hline 4 & 21 & 3 & 6 \\
\hline 5 & 23 & 1 & 2 \\
\hline & Jumlah & 47 & 100 \\
\hline
\end{tabular}

Berdasarkan tabel diatas diketahuinbahwa umur dari 47 responden mahasiswa 
STIKES Yarsi Jurusan Keperawatan Bukittinggi terbanyak yaitu umur 19 tahun sebanyak 23 orang $(48,93 \%)$.

Pengetahuan mahasiswa tentang karies gigi dikelompokkan menjadi 3 kategori yaitu baik, cukup, dan kurang. Hasil penelitian pada 47 orang responden di STIKES Yarsi Jurusan Keperawatan Bukittinggi, maka diperoleh distribusi frekuensi pengetahuan mahasiswa STIKES Yarsi Jurusan Keperawatan tentang karies gigi seperti yang terdapat pada tabel 3 .

Tabel 3. Distribusi Frekuensi Pengetahuan Mahasiswa STIKES Yarsi Jurusan Keperawatan tentang Karies Gigi

\begin{tabular}{cccc}
\hline No & Pengetahuan & Frekuensi & Persentase \\
\hline & mahasiswa & & $(\%)$ \\
\hline 1 & Baik & 10 & 22 \\
\hline 2 & Cukup & 37 & 78 \\
\hline 3 & Kurang & 0 & 0 \\
\hline & Jumlah & 47 & 100 \\
\hline
\end{tabular}

berdasarkan tabel diatas diketahui bahwa, sebagian besar pengetahuan tentang karies gigi berada pada kriteria cukup sebanyak 37 orang ( $78 \%$ ) dan tidak ada yang berpengetahuan kurang.

Tabel 4. Distribusi Frekuensi Indeks DMF-T mahasiswa STIKES Yarsi Jurusan Keperawatan

\begin{tabular}{cccc}
\hline No & Indeks DMF-T & Frekuensi & Persentase (\%) \\
\hline 1 & Baik & 23 & 49 \\
\hline 2 & Jelek & 24 & 51 \\
\hline & Jumlah & 47 & 100 \\
\hline
\end{tabular}

Berdasarkan tabel diatas dapat diketahui bahwa dari 47 responden mahasiswa STIKES Yarsi Jurusan Keperawatan, didapatkan bahwa sebagian besar memiliki indeks DMF-T dengan kriteria jelek yaitu sebanyak 24 orang ( $51 \%$ ).

Tabel 5. Tabulasi Silang Gambaran pengetahuan mahasiswa tentang karies gigi terhadap indeks DMF-T

\begin{tabular}{lccccccc}
\hline \multicolumn{1}{c}{$\begin{array}{l}\text { V. dependent } \\
\text { V.independent }\end{array}$} & Baik & \multicolumn{2}{c}{ Indeks DMF-T } \\
Jelek
\end{tabular}


Berdasarkan tabel 6 terlihat bahwa dari 37 ( $78 \%$ ) mahasiswa memiliki pengetahuan yang cukup tentang karies gigi, ditemukan 17 ( $36 \%$ ) mahasiswa memiliki indeks DMF-T dengan kriteria baik dan 20 ( $42 \%$ ) mahasiswa memiliki indeks DMF-T dengan kriteria jelek.

\section{PEMBAHASAN}

Berdasarkan penelitian yang telah dilakukan terhadap 47 orang responden terlihat bahwa pengetahuan mahasiswa STIKES Yarsi Jurusan Keperawatan tentang karies gigi yang terbanyak yaitu berkriteria cukup sebanyak 37 orang (78\%), berkriteria baik sebanyak 10 orang ( $22 \%$ ) dan tidak ada pengetahuan mahasiswa yang berkriteria kurang.

Peneliti berasumsi, kemungkinan hal ini disebabkan karena pengetahuan mahasiswa yang masih cukup tentang kesehatan gigi dan mulut. Mahasiswa STIKES Yarsi Jurusan Keperawatan juga mempelajari tentang kesehatan gigi dan mulut tapi hanya secara garis besar saja. Sesuai dari wawancara yang telah dilakukan pada mahasiswa STIKES Yarsi Jurusan Keperawatan, mereka mempelajari tentang cara menjaga kesehatan gigi dan mulut seperti cara dan waktu menyikat gigi yang tepat dan makanan yang dapat menyehatkan gigi dan mulut. Mahasiswa juga sering melihat iklan di televisi dan berbagai berita dari internet tentang masalah gigi dan mulut. Kemungkinan pengetahuan responden yang cukup tentang karies gigi dikarenakan responden lebih sedikit mendapatkan pengetahuan tentang karies gigi dibandingkan dengan pengetahuan lainnya. Responden lebih banyak mempelajari tentang ilmu keperawatan di STIKES Yarsi. Hal ini dapat dilihat dari hasil jawaban kuisioner yang diisi oleh mahasiswa STIKES Yarsi Jurusan Keperawatan yang menunjukkan jawaban benar terbanyak responden ada pada pertanyaan yang menanyakan tentang pencegahan terjadinya karies gigi dan penyebab timbulnya karies gigi.Sesuai teori yang mengatakan bahwa sebagian besar pengetahuan manusia diperoleh melalui mata dan telinga (Harto, 2010)

Pengetahuan seseorang juga dipengaruhi oleh beberapa faktor yaitu; 1) pengalaman yang didapatkan dari diri sendiri dan orang lain, 2) tingkat pendidikan dapat membawa wawasan dan pengetahuan seseorang. Secara umum seseorang yang memiliki tingkat pendidikan yang tinggi akan memiliki pengetahuan yang lebih tinggi daripada seseorang yang memiliki tingkat pengetahuan yang rendah, 3) fasilitas sumber informasi seperti televisi, radio, majalah, koran, internet, 4) sosial budaya, kebudayaan dan kebiasaan dalam keluarga dapat mempengaruhi persepsi, pengetahuan dan sikap seseorang terhadap sesuatu (Notoadmojo,2013)

Penelitian ini sependapat dengan penelitian sebelumnya yang berjudul hubungan pengetahuan masyarakat umur 45-54 tahun tentang karies gigi dengan pemanfaatan 
fasilitas pelayanan kesehatan gigi dan mulut di nagari Sarilamak Kecamatan Harau Kabupaten 50 Kota bahwa pengetahuan responden dengan kriteria terbanyak yaitu cukup sebanyak 58,7\% (Masril,2012)

Berdasarkan penelitian pada 47 orang mahasiswa STIKES Yarsi Jurusan Keperawatan, didapatkan indeks DMF-T terbanyak yaitu kriteria jelek sebanyak 24 orang ( $51 \%$ ) dan kriteria baik sebanyak 23 orang ( $49 \%$ ).

Peneliti berasumsi kemungkinan hal ini dikarenakan mahasiswa tidak menjaga kesehatan giginya dan tidak melakukan perawatan pada giginya yang sudah berlubang. Gigi yang sudah berlubang dibiarkan saja dan tidak pernah dibawa ke tenaga kesehatan gigi untuk dilakukan perawatan. Hal ini dapat dilihat dari hasil pemeriksaan yang dilakukan pada mahasiswa STIKES Yarsi Jurusan keperawatan yang didapatkan tidak adanya angka Filling ( $F$ ) pada indeks DMF-T mahasiswa.

Sesuai teori yang mengatakan bahwa penambalan terhadap gigi yang berlubang sebaiknya dilakukan sedini mungkin sebelum kelainannya menjadi lebih berat lagi. Apabila penambalan dilakukan sedini mungkin, kunjungan ke dokter gigi menjadi lebih sedikit dalam artian sekali datang bisa dilakukan penambalan langsung apabila kelainannya sudah lebih berat maka gigi tersebut harus dilakukan perawatan terlebih dahulu sehingga memerlukan kunjungan yang lebih

banyak (Malik,2008).

Hasil penelitian sejalan dengan penelitian sebelumnya yang berjudul gambaran tingkat pengetahuan mahasiswa tentang karies gigi terhadap indeks DMF-T pada mahasiswa tingkat 1 Jurusan Keperawatan Gigi Bukittinggi tahun 2009 bahwa indeks DMFT dengan kriteria jelek lebih banyak dibandingkan indeks DMF-T kriteria baik, dimana indeks DMF-T dengan kriteria jelek sebanyak 53,1 \%.22 pada mahasiswa Jurusan Keperawatan Gigi Bukittinggi (Nila, 2009).

Berdasarkan hasil penelitian yang telah dilakukan pada 47 orang mahasiswa STIKES Yarsi Jurusan Keperawatan, dapat diketahui bahwa 37 ( $78 \%$ ) orang mahasiswa memiliki pengetahuan yang cukup tentang karies gigi, dengan 17 ( $36 \%$ ) mahasiswa memiliki indeks DMF-T dengan kriteria baik dan 20 ( $42 \%$ ) mahasiswa memiliki indeks DMF-T dengan kriteria jelek dan 10 ( $22 \%$ ) mahasiswa memiliki pengetahuan yang baik tentang karies gigi, dengan 6 (13\%) mahasiswa memiliki indeks DMF-T dengan kriteria baik dan 4 ( $9 \%$ ) mahasiswa memiliki indeks DMF-T dengan kriteria jelek.

Peneliti berasumsi bahwa hal ini menunjukkan masih tingginya angka karies gigi pada mahasiswa STIKES Yarsi Jurusan Keperawatan dikarenakan mahasiswa belum menerapkan pengetahuan yang diperoleh tentang kesehatan gigi oleh para responden dalam kehidupan sehari-hari, yang menunjukkan bahwa pengetahuan yang diterima belum 
dapat meningkatkan kesadaran dan merubah perilaku pada diri respoden untuk menjaga kesehatan gigi dan mulutnya, ini menunjukkan bahwa pengetahuan yang dimiliki mahasiswa dengan indeks DMF-T tidak sejalan.

Pengetahuan yang cukup mengenai kesehatan gigi merupakan faktor predisposisi dari perilaku kesehatan yang mengarah pada timbulnya penyakit. Pengetahuan ini erat pula kaitannya dengan sikap seseorang terhadap penyakit dan upaya pencegahnnya. Kepercayaan seseorang terhadap kerentanan dirinya dari suatu penyakit dan potensi penyakit, akan menjadi dasar seseorang melakukan tindakan pencegahan atau pengobatan terhadap penyakit tersebut (Notoadmojo, 2005).

$\mathrm{Hal}$ ini sejalan dengan penelitian yang berjudul hubungan pengetahuan pasien tentang karies gigi terhadap indeks DMF-T pada pasien yang berkunjung ke poli gigi Puskesmas Air Dingin tahun 2012 bahwa sebagian besar pengetahuan responden memiliki kriteria sedang (cukup) 98,7\% dan responden dengan indeks DMF-T kriteria jelek $72 \%$ (Yulfida, 2012)

\section{SIMPULAN DAN SARAN}

Dapat disimpulkan bahwa 37 orang (78 \%) memiliki pengetahuan cukup dan 10 orang (22\%) memiliki pengetahuan baik tentang karies gigi, sedangkan 24 orang (51\%) memiliki indeks DMF-T dengan kriteria jelek dan 23 orang (49\%) memiliki indeks DMF-T dengan kriteria baik. Kesimpulan dalam penelitian ini yaitu pengetahuan mahasiswa tentang karies gigi dengann kriteria cukup mempunyai indeks DMF-T jelek. Disarankan kepada responden untuk lebih meningkatkan pengetahuan tentang cara menjaga kesehatan gigi dan mulut. 


\section{DAFTAR PUSTAKA}

Basri. M. Faktor yang berhubungan dengan timbulnya karies gigi pada anak 10 tahun di SD Talakuwe Kecamatan Bajeng Barat Kabupaten Gowa. [Proposal penelitian]. Selasa, 07 april 2016

Harto B. Pengantar ilmu perilaku kesehatandan pendididkan kesehatan gigi. Penerbit buku kedokteran. EGC. Jakarta. 2010

Kidd M. A. Edwina. Dasar-dasar karies penyakit dan penanggulangannya. Penerbit buku kedokteran. EGC. Jakarta. 2013

Malik Isnaniah. Kesehatan gigi dan mulut. Fakultas kedokteran gigi Universitas Padjadjaran. Bandung. 2008 [Makalah PDF].

Masril Elija. Hubungan pengetahuan masyarakat umur 45-54 tahun tentang karies gigi dengan pemanfaatan fasilitas pelayanan kesehatan gigi dan mulut di nagari Sarilamak Kecamatan Harau Kabupaten 50 Kota. 2012. [Karya Tulis IImiah]

Taringan R. Karies Gigi. Penerbit buku kedokteran gigi. Jakarta. EGC. 2013

Nila. Gambaran tingkat pengetahuan mahasiswa tentang karies gigi terhadap indeks DMF-T pada mahasiswa tingkat 1 Jurusan Kesehatan Gigi Bukittinggi. 2009 [Karya Tulis IImiah]

Notoatmodjo S. Promosi kesehatan, teori dan aplikasi. PT Rineka Cipta. Jakarta. 2005

Notoatmodjo S. Pendidikan dan perilaku kesehatan. PT Rineka Cipta. Jakarta. 2013

Riset Kesehatan Dasar (RisKesDas). Kesehatan Gigi dan Mulut. RisKesDas RI. 2013;362;146-154. 2013

Rita D. Gambaran tingkat kepatuhan anak menggosok gigi terhadap indeks DMF-T anak usia 10-12 tahun di SDS Islam Al Azhar kelurahan Bukit Apit Keecamatan Guguk Panjang. [Karya tulis ilmiah]. 2006

Yulfida. Hubungan pengetahuan pasien tentang karies gigi terhadap indeks DMF-T pada pasien yang berkunjung kepoli gigi Puskesmas Air Dingin. 2012. [Karya Tulis Ilmiah] 